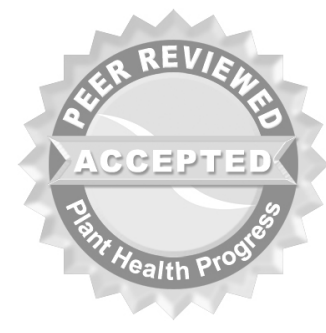

(c) 2013 Plant Management Network.

Accepted for publication 7 August 2012. Published 24 October 2013.

\title{
Evaluation of Foliar Fungicide Sprays for the Control of Boxwood Blight, Caused by the Fungus Cylindrocladium buxicola
}

\author{
B. Henricot, Plant Pathology Department, The Royal Horticultural \\ Society (RHS), Wisley, Woking, Surrey GU23 6QB, UK; and \\ E. Wedgwood, ADAS Boxworth, Battlegate Road, Boxworth, \\ Cambridgeshire CB23 4NN, UK
}

Corresponding author: B. Henricot. beatricehenricot@rhs.org.uk

Henricot, B., and Wedgwood, E. 2013. Evaluation of foliar fungicide sprays for the control of boxwood Blight, caused by the fungus Cylindrocladium buxicola. Online. Plant Health Progress doi:10.1094/PHP-2013-1024-01-RS.

\begin{abstract}
Cylindrocladium buxicola causes a damaging blight disease on boxwood which has spread rapidly throughout Europe since introduction of the pathogen in England in the mid 1990s. The pathogen has also been recently identified in the USA and British Columbia. The disease is difficult to control using cultural methods and information about chemical control is lacking. To address this, preventative and curative foliar fungicide sprays previously shown in laboratory tests to have efficacy were evaluated over two autumn/winter seasons in the UK. Results from the first autumn/winter season showed that the premix product Opponent (epoxiconazole + kresoxim-methyl + pyraclostrobin) was the best treatment when applied preventatively 3 days before inoculation. In the second autumn/winter season, curative treatment of diseased plants was best achieved with a weekly program of fungicides starting 3 days before inoculation and alternating with two or three products including Bravo (chlorothalonil), Signum (boscalid + pyraclostrobin), and Octave (prochloraz). The only fungicide tested and available to amateur growers in the UK, Fungus Clear (penconazole), was found to give moderate control of boxwood blight.
\end{abstract}

\section{Introduction}

Boxwood blight, caused by Cylindrocladium buxicola nom. cons. prop. $(=C$. pseudonaviculatum $(7,15,16)$, is the most destructive foliar disease of boxwood (Buxus spp.). The fungus causes leaf spots and black stem lesions followed by defoliation and dieback. Severe dieback can lead to death of plants, especially young seedlings. Cases of the disease have been reported widely throughout Europe since it was first recorded in 1994 in the UK $(3,5,6,12,15,18,24,25)$. Outside Europe the disease occurs in New Zealand (15) and has also recently been found in the USA and British Columbia $(9,20)$. C. buxicola is a threat to boxwood growing in commercial nurseries, landscapes, public gardens, and parks as well as native populations of boxwood around the world. The fungus appears to be confined to the family of Buxaceae (17) and infects many species in the genus Buxus including B. balearica, B. bodinieri, B. glomerata, B. harlandii, $B$. macowanii, and $B$. riparia. These species grow naturally over the four different continents Africa, Central America, Asia, and Europe (1). In the UK, the disease is widespread with an increasing incidence in gardens (14) and has been confirmed on native $B$. sempervirens growing wild, posing a threat to this unique habitat. The fungus may be spread in wind-blown rain but needs a vector to travel long distances (15), and can remain viable for at least 5 years on fallen boxwood material (17). It can also survive as microsclerotia in the soil (8). $C$. buxicola has also been spread widely on infected plants in plant trade. Control measures include pruning of infected twigs, destruction of fallen leaves, and increased sanitation to help reduce inoculum. 
Data is lacking on fungicide efficacy for this disease. Preliminary in vitro experiments showed that the fungicides Stroby (kresoxim-methyl), Opponent (epoxiconazole + kresoxim-methyl + pyraclostrobin), Opera (epoxiconazole + pyraclostrobin), and Signum (boscalid + pyraclostrobin) were the most effective at inhibiting growth of mycelium and germination of conidia (17). Other active ingredients such as carbendazim, chlorothalonil, prochloraz, and penconazole showed mixed activities in vitro. Penconazole was the only fungicide tested that was available to amateur gardeners in the UK. The current study was conducted to evaluate the efficacy of these fungicides against the disease under field conditions. The fungicides were tested on English Boxwood, B. sempervirens 'Suffruticosa,' a variety associated with most cases of the disease and also the most susceptible in pathogenicity assays (17). In the first year, fungicides were initially tested as single sprays, evaluating their potential as protectant and curative applications. During the second year of the project, various combinations of the most successful treatments from year one were evaluated as spray programs.

\section{Infection Trials on Container B, sempervirens (September 2006-March 2007)}

Three-year-old B. sempervirens 'Suffruticosa' grown in 15-cm-diameter (1liter) pots were imported from the Netherlands at least one month before the application of fungicides. The experiment took place at the agricultural and environmental consultancy ADAS Arthur Rickwood (Cambridge, UK). The plants were placed outdoor on a woven polypropylene groundcover MyPex. The area was covered and had a central line of overhead irrigation. Plants were given a dressing of Basacote Plus 16-18-12 slow-release fertilizer (six months release) at the start of the experiment at a rate of $3 \mathrm{~g}$ per pot. Overhead sprinkle irrigation was provided for three daily periods during the first two weeks and then once daily until the end of October. A single spore culture of $C$. buxicola (PT25, genotype G1, K. Heungens, personal communication) was obtained from a naturally infected $B$. sempervirens. It was selected for its sporulation abilities and aggressiveness on $B$. sempervirens 'Suffruticosa.' Suspensions of conidia used for infection were prepared as follows. The cultures were grown on potatodextrose agar (PDA; Oxoid, Basingstoke, UK) at $25^{\circ} \mathrm{C}$ in the dark. Several mycelia plugs from 7-day-old PDA cultures were placed onto carnation leaf agar (CLA) (11) and synthetic nutrient agar (SNA;1 $\mathrm{g} \mathrm{KH}_{2} \mathrm{PO}_{4}, 1 \mathrm{~g} \mathrm{KNO}_{3}, 0.5 \mathrm{~g}$ $\mathrm{MgSO}_{4} 7 \mathrm{H}_{2} \mathrm{O}, 0.5 \mathrm{~g} \mathrm{KCl}, 0.2 \mathrm{~g}$ glucose, $0.2 \mathrm{~g}$ sucrose, and $20 \mathrm{~g}$ agar/liter distilled water, $\mathrm{pH}$ 6-6.5) media and incubated at $25^{\circ} \mathrm{C}$ under near ultraviolet light for 10-15 days. The spore suspension was made by adding sterile distilled water to which Tween $20(0.1 \% \mathrm{v} / \mathrm{v})$ was added. The number of conidia was counted with a haemocytometer and a suspension of $1.2 \times 10^{5}$ spores $/ \mathrm{ml}$ was used to inoculate plants. Plants were inoculated on 11 September 2006 using a Hoselock hand pump sprayer. The upper surfaces of all leaves of the experimental plants were inoculated with $25 \mathrm{ml}$ of spore suspension per plot; guard plants were not inoculated. Distilled water with added Tween 20 (0.1 \% v/v) was sprayed on each of the uninoculated control plants. The disease was encouraged to develop by providing humid conditions under polyethylene. The cover was removed after $24 \mathrm{~h}$. Seven fungicides (Table 1) were applied as protectant and curative foliar sprays. These were kresoxim-methyl (Stroby WG; BASF, Cheadle Hulme, UK), carbendazim (Delsene 50 Flo; Nufarm UK, Belvedere, UK), chlorothalonil (Bravo 500; Syngenta Crop Protection UK Ltd, Cambridge, UK), prochloraz (Scotts Octave; Scotts, Ipswich, UK), azoxystrobin (Amistar; Syngenta Crop Protection UK Ltd, Cambridge, UK), penconazole (Fungus Clear; The Scotts Company Ltd, Godalming, UK), epoxiconazole + kresoxim-methyl + pyraclostrobin (Opponent; BASF, Cheadle Hulme, UK ). All products were applied at label rates either for ornamentals, or if not available for other crops under Long Term Arrangements for Use. When applied preventatively, products were applied 3 days before inoculation and not followed by further applications. When applied curatively, products were applied when symptoms first developed, 6 days after inoculation. These were applied three times, at 7-day intervals, except for Delsene Flo and Opponent which were applied twice at a 14-day 
interval according to label specifications. To prevent spray drift, a plastic guard was placed around each plot as the fungicide was applied. There were two noninoculated, and two inoculated controls without fungicide treatment and 18 treatments in total. All applications were made as foliar sprays at 0.02 liter per plot to the point of run-off. Applications were given to each plot using a gasassisted knapsack sprayer (Oxford type) with a 0.5-m spray band width and a single 02 F110 nozzle at 30 psi.

Table 1. Fungicides used for testing against Cylindrocladium buxicola in Year 1 (2006-2007) and Year 2 (2008-2009).

\begin{tabular}{|c|c|c|c|}
\hline $\begin{array}{l}\text { Active } \\
\text { ingredient(s) }\end{array}$ & Formulation & Product & $\begin{array}{c}\text { Rate of } \\
\text { product used } \\
\text { (per liter) }\end{array}$ \\
\hline Kresoxim-methyl & $50 \% W^{x}$ & Stroby WG & $0.6 \mathrm{~g}$ \\
\hline Carbendazim & $50 \%$ SCx & Delsene 50 Flo & $1.0 \mathrm{ml}$ \\
\hline Chlorothalonil & $50 \% \mathrm{SC}^{\mathrm{x}}$ & Bravo 500 & $2.2 \mathrm{ml}$ \\
\hline Prochloraz & $46 \%$ WPx & Scotts Octave & $1.0 \mathrm{~g}$ \\
\hline Azoxystrobin & $25 \% \mathrm{SC}^{\mathrm{x}}$ & Amistar & $2 \mathrm{ml}$ \\
\hline Penconazole & $1.54 \%$ SCX & Fungus Clear & $10 \mathrm{ml}$ \\
\hline $\begin{array}{l}\text { Epoxiconazole }+ \\
\text { kresoxim-methyl }+ \\
\text { pyraclostrobin }\end{array}$ & $\begin{array}{l}5 \%+ \\
6.7 \%+ \\
13.3 \% \text { SEx }\end{array}$ & Opponent & $3 \mathrm{ml}$ \\
\hline $\begin{array}{l}\text { Boscalid }+ \\
\text { pyraclostrobin }\end{array}$ & $\begin{array}{l}26.7 \%+ \\
6.7 \% \text { WGx }\end{array}$ & Signum & $3 \mathrm{~g}$ \\
\hline $\begin{array}{l}\text { Epoxiconazole + } \\
\text { pyraclostrobin }\end{array}$ & $\begin{array}{l}5 \%+ \\
13.3 \% \text { SEx }\end{array}$ & Opera & $3 \mathrm{ml}$ \\
\hline
\end{tabular}

The plants were assessed individually and in the same order 3 days postinoculation (dpi) on 14 September 2006 and then again on 18 and 25 September and 2 October 2006 before each of 3 curative fungicide applications were applied at 7-day intervals. Further disease assessments were made on 9 and 16 October, 6 and 13 days after the last curative fungicide application. To determine long-term effect of applications, assessments were carried out on a monthly basis up to six months after inoculation (16 November 2006; 14 December 2006; 16 January 2007; 16 February and 16 March 2007). Disease severity was assessed in such a way that the various stages of foliar and stem infection were measured as they developed, using the criteria: percentage of leaf drop (\% leaf drop), percentage of leaf spot (\% leaf spot), percentage of black streak areas on stems (\% stem streaking), and percentage of dieback (\% stem dieback).

Following the destructive sampling of three whole plants, the average number of leaves on one plant was estimated at 1000 whereas the average total stem length was averaged at $1000 \mathrm{~cm}$ per plant. The \% leaf spot and \% leaf drop was calculated based on the average 1000 leaves per plant and the \% stem streaking and stem dieback was calculated a percentage of a total stem length of $1000 \mathrm{~cm}$. A disease score ranging from o to 200 was then calculated by summing up the percentages of leaf and stem symptoms. Three days after each of the fungicide applications, assessments of chemical phytotoxicity were made based on the \% leaf area per plot affected. Any visible spray residues were recorded. The experiment was a randomised complete block design with 4 blocks. Within each replicate block there were 18 plots $(68 \times 90 \mathrm{~cm})$, each with 10 plants organized in three columns of pots with 14 guard plants surrounding each plot. Guard plants are used to reduce the edge-effects. There were four replicates for the fungicide treated plots each occurring once per block and eight replicate plots each for the inoculated and non-inoculated controls, each occurring twice per block. The assessment data from 10 plants per plot were averaged for analysis. 
Analysis of variance (ANOVA) using Genstat 12th edition (23) was used to determine the effect of inoculation and fungicide treatment at each date.

The results of the fungicide treatments are presented in Fig. 1. Throughout the trial the non-inoculated plants remained uninfected while disease severity increased on the inoculated untreated controls. Over the period of assessment the disease symptoms progressed from leaf spot to leaf drop followed by stem streaking and stem dieback (data not shown). In general the percentage of leaf spot increased until $14 \mathrm{dpi}$, after which the percentage of leaf drop increased resulting in a decrease in the amount of recordable leaf spot due to loss of leaves. The percentage of stem streaking started to increase 21 dpi (2 October 2006) and continued until two months after inoculation (16 November 2006). Stem dieback started $28 \mathrm{dpi}$. The disease severity peaked two months after inoculation (16 November 2006) after which there was little disease progress (Fig. 1).

Opponent applied preventatively was the best treatment for reducing disease progress over the period of assessment; plants treated with Opponent had a disease score similar to the non-inoculated control (Fig. 1A). Bravo 500 was the next best preventative treatment; plants treated with Bravo 500 showed significantly less disease $14 \mathrm{dpi}(P<0.05)$ until the disease peaked at $66 \mathrm{dpi}$. Preventative application of Amistar, Octave and Stroby did not effectively control the disease. Fungus Clear had a mid-range effect and provided some disease control, but that effect was not statistically significant when the disease peaked 66 dpi until the end of the assessment (182 dpi).

The best curatively-applied products were Octave and Opponent which started to have an effect 14 dpi with plants developing less disease symptoms than other treatments $(P<0.05)$ (Fig. 1B). The fungicides Amistar and Delsene Flo5o applied curatively gave the poorest control. The fungicides Bravo 500 and Fungus Clear applied curatively gave some mid-range control but their effect was not significantly different from the untreated inoculated control (Fig. 1B).

The disease severity was significantly higher $(P<0.001)$ in the first block of plants and this difference persisted throughout the assessment period of the trial (data not shown). The first block was alongside a mesh windbreak that both shaded and sheltered these plots, allowing the plants to remain wet longer after the regular overhead irrigation period.

\section{Infection Trials on Container B. sempervirens (September 2008-March 2009)}

In year two (2008-2009), the experiment was located at ADAS Boxworth (Cambridge, UK). Three-year-old B. sempervirens 'Suffruticosa' grown in 15$\mathrm{cm}$-diameter (1-liter) pots were imported from the Netherlands. The design of the experiment was the same as year one except the plants were irrigated three times a day for 5 -min intervals for the first two weeks. After this time, to increase the duration of leaf wetness, six equally spaced 3-min irrigation intervals were given between 07:00 and 22:00 hours until the end of October. Windbreak-netting fences and a canopy were used to reduce air movement and shade the plants to help maintain leaf wetness.

The C. buxicola inoculum (same isolate PT25) was prepared and inoculation was carried out as described above. A suspension of $1 \times 10^{4}$ spores $/ \mathrm{ml}$ was used to inoculate plants. The upper surfaces of all the leaves of the experimental plants were inoculated with $100 \mathrm{ml}$ of spore suspension per plot on 11 September 2008.

Six fungicides (Table 1) including kresoxim-methyl, chlorothalonil, prochloraz, penconazole, epoxiconazole + pyraclostrobin (Opera, BASF, Cheadle Hulme, UK), boscalid + pyraclostrobin (Signum; BASF, Cheadle Hulme, UK) were applied as protectant or curative foliar sprays or both protectant and curative foliar sprays on the application dates given in Table 2. Product selection and application timing were based on results from year one. Opponent was replaced by Opera since at the time Opponent was no longer sold by BASF. All preventative treatments were sprayed 3 days before inoculation. Curative sprays were applied three times, at 7-day intervals, except for Opera and Signum which were applied twice at a 14-day interval according to label specifications. 


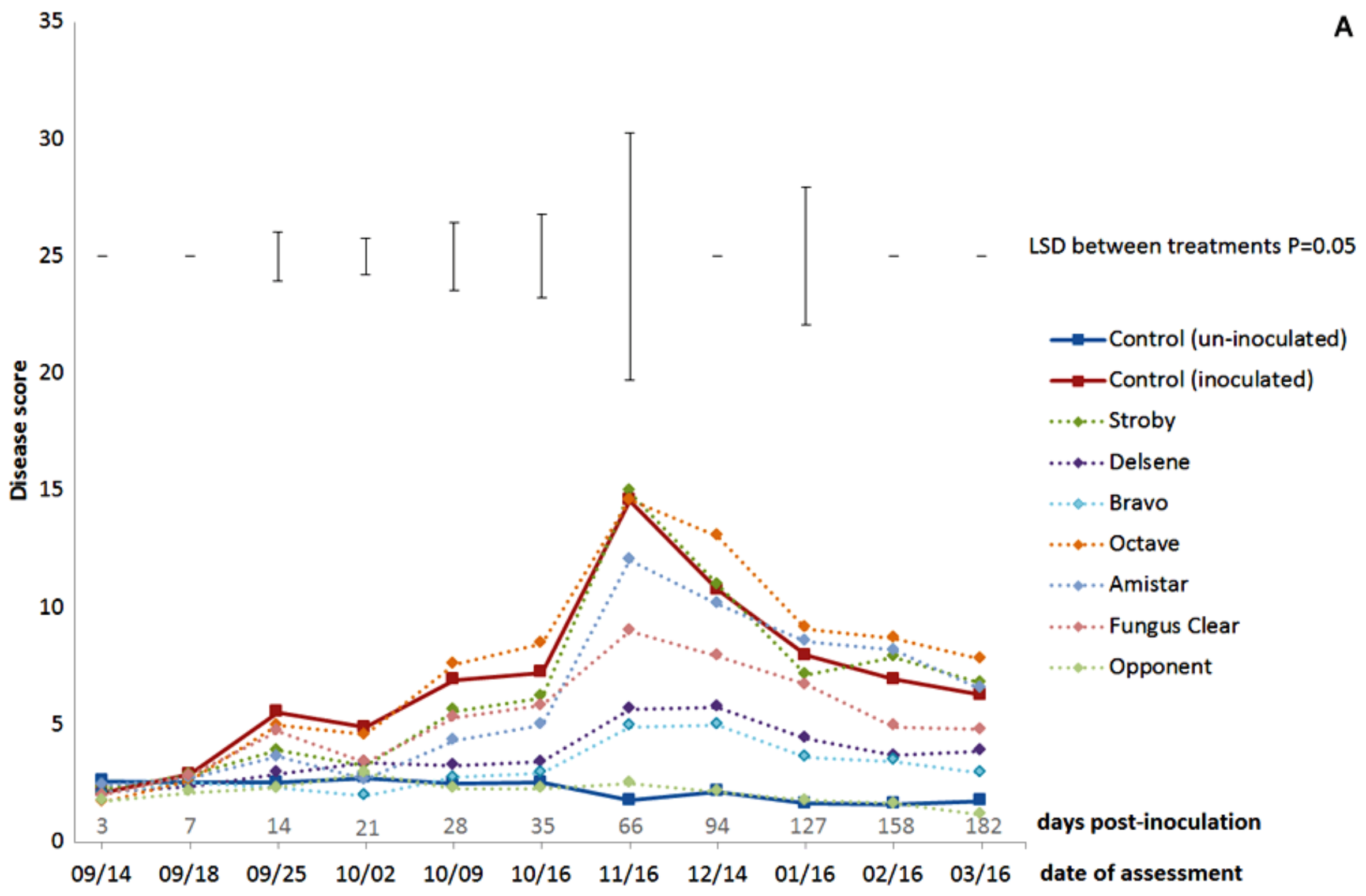




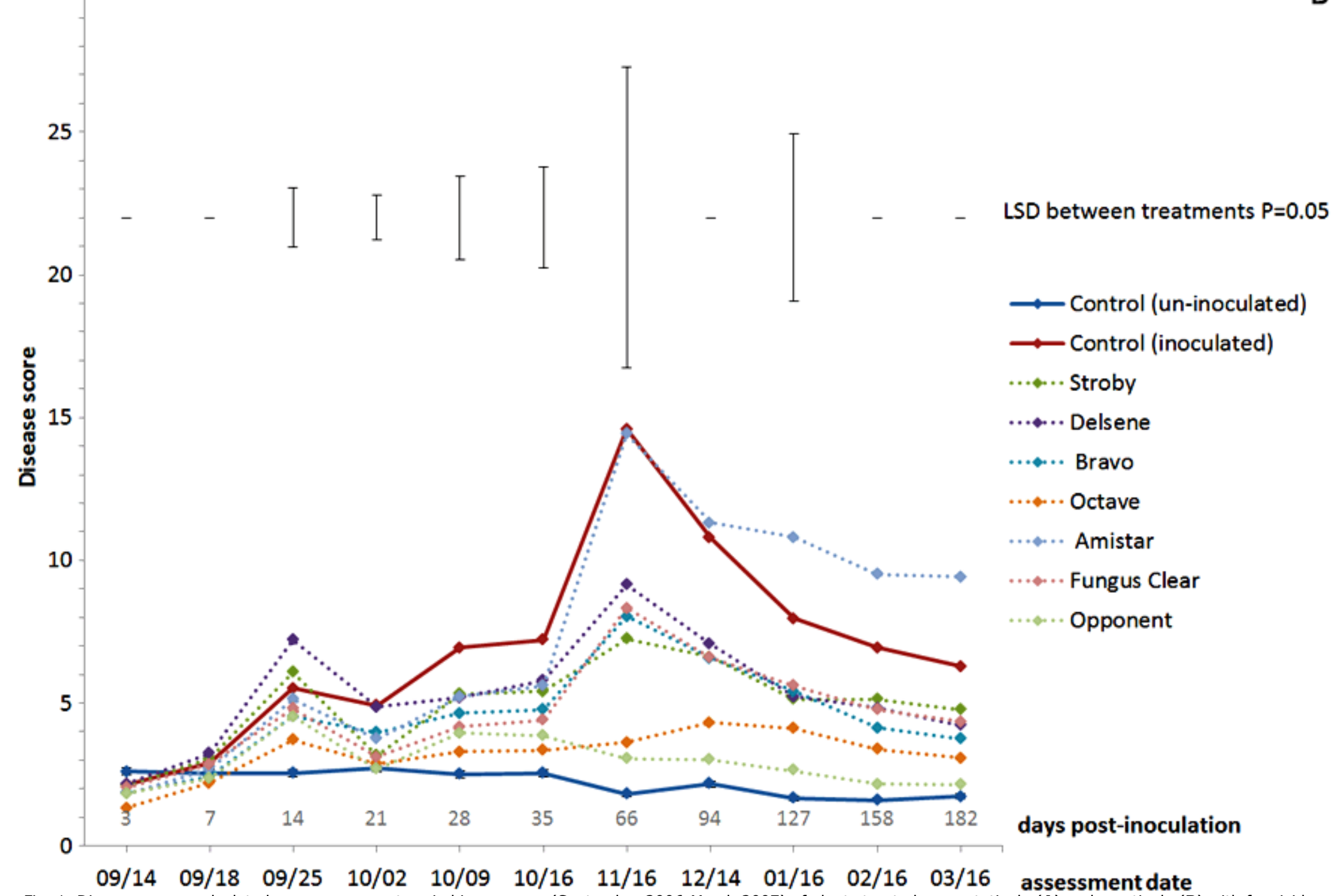

Fig. 1. Disease scores calculated over assessment period in year one (September 2006-March 2007) of plants treated preventatively (A) and curatively (B) with fungicides and uninoculated and inoculated untreated controls. Values represent the means of 4 replicates of treated plots and 8 replicates of inoculated and non-inoculated untreated control plots. Bars represent LSD with the highest value (LSD relating to differences between fungicides) (5\% level). LSDs are not shown when there was no treatment effect $(P>0.05)$. 
Different combinations of products were applied as curative and preventative treatments as described in Table 2. Fungus Clear alone was used in a single treatment to simulate home garden use. Details on the rates of fungicide application (22) are given in Table 1. The plants were assessed as described for year one but natural infection occurred and was assessed 10 days before inoculation and prior to the application of the preventative spray. Assessments were conducted 4 dpi on 15 September before the first curative application. Further assessments were made on 22 and 29 September before the other two curative fungicide applications. Subsequent assessments were made on 6 and 13 October, 3 and 24 November, and then again on 16 February and 16 March in 2009. The statistical design of the experiment was the same as for year one but with 20 treatments. Analysis of variance (ANOVA) using Genstat 12th edition (23) was used to determine treatment effects.

Table 2. Dates of fungicides applications against Cylindrocladium buxicola in Year 2 (2008-2009).

\begin{tabular}{|l|l|l|l|l|}
\hline \multirow{2}{*}{$\begin{array}{l}\text { Treatment } \\
\text { no. }\end{array}$} & \multicolumn{5}{|c|}{ Time of fungicide application } \\
\cline { 2 - 5 } & Preventative & Curative 1 & Curative 2 & Curative 3 \\
\cline { 2 - 5 } & $\mathbf{0 9 / 0 8 / 0 8}$ & $\mathbf{0 9 / 1 6 / 0 8}$ & $\mathbf{0 9 / 2 3 / 0 8}$ & $\mathbf{0 9 / 3 0 / 0 8}$ \\
\hline T5 & Opera & - & - & - \\
\hline T6 & Bravo 500 & - & - & - \\
\hline T7 & Signum & - & - & - \\
\hline T8 & - & Octave & Octave & Octave \\
\hline T10 & - & Stroby & Stroby & Stroby \\
\hline T11 & - & Bravo 500 & Bravo 500 & Bravo 500 \\
\hline T12 & - & Opera & - & Opera \\
\hline T13 & Opera & Signum & - & Signum \\
\hline T14 & Opera & Bravo 500 & - & Bravo 500 \\
\hline T15 & Opera & Bravo 500 & Stroby & Bravo 500 \\
\hline T16 & Bravo 500 & Bravo 500 & Opera & Bravo 500 \\
\hline T17 & Bravo 500 & Stroby & Bravo 500 & Stroby \\
\hline T18 & Opera & Octave & Opera & Octave \\
\hline T19 & Fungus Clear & Fungus Clear & Fungus Clear & Fungus Clear \\
\hline T20 & Signum & Octave & Signum & Octave \\
\hline
\end{tabular}

The results of the fungicide treatments are presented in Fig. 2. Symptoms developed slower than in year one. Percent leaf spot increased until 74 dpi (24 November). Stem streaking started to appear 53 dpi (3 November) and stem dieback was visible $74 \mathrm{dpi}$ (24 November) (results not shown). Disease symptoms increased exponentially, with the fastest increase between $32 \mathrm{dpi}$ and 74 dpi (13 October and 24 November 2008) and peaked 5 months after inoculation (16 February 2009) (Fig. 2).

Initially, by 18 dpi (29 September), T14 (Opera, Bravo 500, Stroby, Bravo 500 ) was the only treatment with significantly less disease than the untreated inoculated control $(P<0.05)$. However, by 74 dpi $(24$ November), all fullprogram treatments (T13, T15, T16, T17, T18, and T20) except Fungus Clear (T19) and all single fungicide treatments except Opera (T5) and Bravo (T6) applied preventatively had significantly less disease symptoms than the untreated inoculated control $(P<0.05)$ until the end of assessments (Fig. 2). In previous laboratory tests, Opponent, Opera, Bravo 500, and Signum were all shown to be effective in inhibiting conidia germination (17), suggesting 


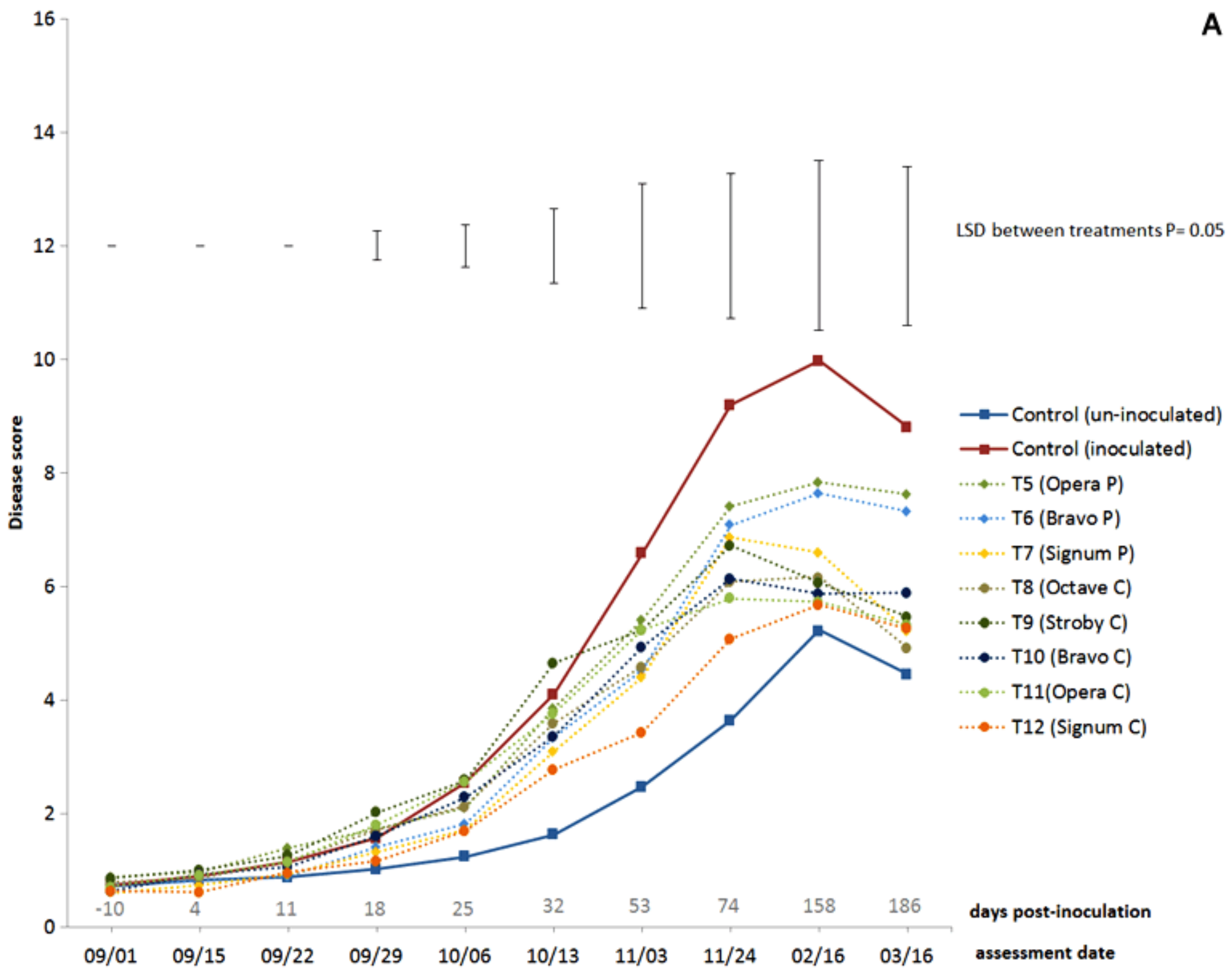




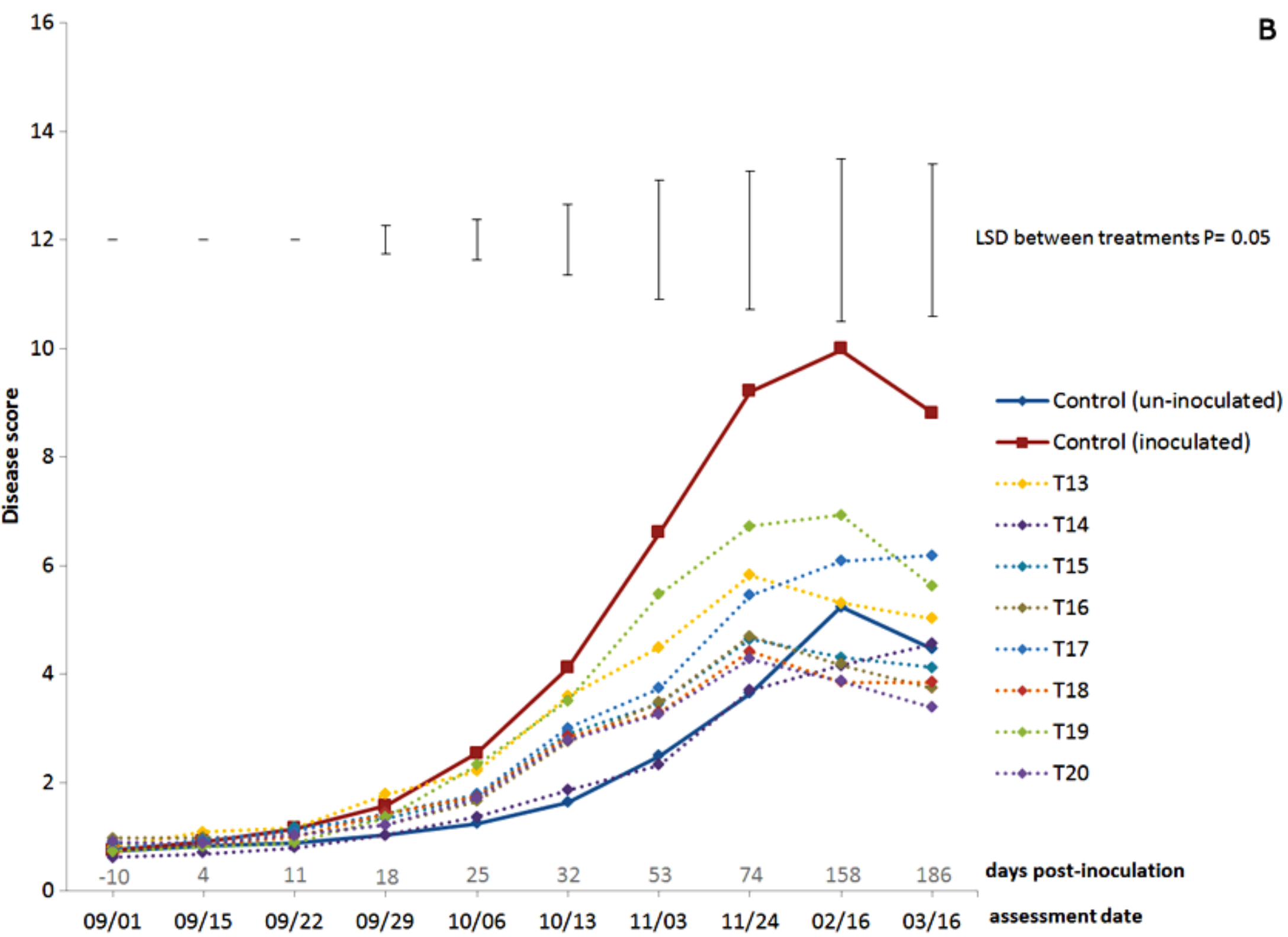

Fig. 2. Disease scores calculated over assessment period in year two (September 2008-March 2009) of plants treated with (A) a single fungicide applied preventatively (P) or curatively (C) and uninoculated and inoculated untreated controls; (B) with a mixture of fungicides and inoculated and non-inoculated untreated controls. Treatments T5-T20 are described in Table 2. Values represent the means of 4 replicates of treated plots and 8 replicates of inoculated and non-inoculated untreated control plots. Bars represent LSD with the highest value (LSD relating to differences between fungicides) ( $5 \%$ level). LSDs are not shown when there was no treatment effect $(P>0.05)$. 
that these fungicides should be effective in protecting plants against the disease. In year two however, the infection pressure was higher than in year one with natural infection occurring before the trial started, thus reducing the effectiveness of the preventative-only treatments (Fig. 2A). As the trial progressed, the guard plants showed obvious signs of infection thus increasing the disease pressure. The use of preventative treatments may be ineffective if applied in the latent phase of infection.

Signum has been found to provide similar or superior results when compared with reference fungicides on several fungal leaf spot and fruit rot diseases of outdoor vegetables and strawberries $(4,13)$. In an earlier study, Signum was usually more effective at inhibiting mycelial growth in vitro than inhibiting conidia germination (17). In these field trials, it was the best fungicide when used as a protectant and a curative in the single-sprays treatment. When used with Octave in a full program (T2O) it gave the best control of boxwood blight. The use of curative applications of Octave (prochloraz) in T16 rather than Stroby (kresoxim-methyl) in T17 improved effectiveness. Indeed, the disease score for plants treated with T16 was lower compared to T17 although not statistically significant. Due to mode of action, prochloraz has been shown to have good curative activity in various fungal pathosystems $(2,10,21,26,28)$ whereas kresoxim-methyl is not considered to have curative activity especially on pathogens that colonize intercellular spaces because they grow away from where the compound accumulates $(19,27)$. The omission of curative applications of Stroby or Opera in T13 gave less satisfactory disease control than in T14 and T15 where either was alternated with Bravo 500, although the differences were not significant.

Plants were examined for phytotoxicity during both trials, although none developed. There were no treatment effects on vigor and no spray residues were observed.

\section{Conclusions}

This is the first series of field data regarding the efficacy of a range of fungicides for the control of $C$. buxicola on English boxwood. Until recently, fungicide assays have only been carried out in vitro hence the need to validate preliminary data obtained in the laboratory under field conditions on boxwood plants. The fungicide Opponent (epoxiconazole + kresoxim-methyl + pyraclostrobin) was the most effective for protecting boxwood from infection under our experimental conditions. Its use on ornamentals in the UK will necessitate a change of label. Alternatively, Bravo (chlorothalonil) can be used and is currently available for use on ornamentals to commercial growers of nursery stock. Treating the disease is more difficult but a program of treatments including Octave (prochloraz) and Signum (boscalid + pyraclostrobin) was the best under our experimental conditions. For amateur use, the fungicide Fungus Clear (penconazole) helped reduce boxwood blight severity but was less effective than other treatments tested. Therefore in home gardens and landscapes, the disease will continue to be difficult to control.

\section{Acknowledgments}

The authors would like to thank Geoff and Jenny Denton, Ian Waghorn, the ADAS team for their technical assistance and Chris Dyer and Andy Peace for their help with the statistical analyses.

\section{Literature Cited}

1. Batdorf, L. R. 2004. Boxwood An Illustrated Encyclopedia. The American Boxwood Society, Boyce, VA.

2. Boneti, J. I. S., and Katsurayama, Y. 1992. Greenhouse evaluation of the protective, curative and postsymptom activities of sterol-inhibiting fungicides on apple scab control. Fitopatol. Bras. 17:412-419.

3. Brand, T. 2005. Auftreten von Cylindrocladium buxicola B. Henricot an Buchsbaum in Nordwest-Deutschland. Nachrichtenbl. Dtsch. Pflanzenschutzdienstes 57

(12):237-240. 
4. Callens, D., Sarrazyn, R., and Evens, W. 2005. Signum, a new fungicide for control of leaf diseases in outdoor vegetables. Commun. Agric. Appl. Biol. Sci. 70:199-207.

5. Cech, T., Diminic, D., and Heungens, K. 2010. Cylindrocladium buxicola causes common box blight in Croatia. New Disease Reports 22:9.

6. Crepel, C., and Inghelbrecht, S. 2003. First report of blight on Buxus spp. caused by Cylindrocladium buxicola in Belgium. Plant Dis. 87:1539.

7. Crous, P. W., Groenewald, J. Z., and Hill, C. F. 2002. Cylindrocladium pseudonaviculatum sp. nov. from New Zealand, and new Cylindrocladium records from Vietnam. Sydowia 54:23-34.

8. Dart, N. L., Arrington, S. M., and Weeda, S. M. 2012. Flaming to reduce inocula of the boxwood blight pathogen, Cylindrocladium pseudonaviculatum, in Field Soil. Online. Plant Health Progress doi:10.1094/PHP-2012-1026-01-BR.

9. Elmhirst, J. F., Auxier, B. E., and Wegener, L. A. 2013. First report of box blight caused by Cylindrocladium pseudonaviculatum (C. buxicola) in British Columbia, Canada. Plant Dis. 97:559.

10. Fischer, I. H., Lourenco, S. A., Martins, M. C., Kimati, H., and Amorim, L. 2005. Selection of resistant plants and fungicides for the control of passion fruit collar rot, caused by Nectria haematococca. Fitopatol. Bras. 30:250-258.

11. Fisher, N. L., Burgess, L. W., Toussoun, T. A., and Nelson P. E. 1982. Carnation leaves as a substrate and for preserving cultures of Fusarium species. Phytopathology 72:151-153.

12. Gorgiladze, L., Meparishvili, G., Sikharulidze, Z. , Natsarishvili, K., and Davitadze, R. 2011. First report of box blight caused by Cylindrocladium buxicola in Georgia. New Dis. Rep. 23:24.

13. Hauke, K., Creemers, P., Brugmans, W., and Van Laer, S. 2004. Signum, a new fungicide with interesting properties in resistance management of fungal diseases in strawberries. Commun. Agric. Appl. Biol. Sci. 69:743-755.

14. Henricot, B. 2006. Box blight rampages onwards. September issue, The Plantsman 5:153-157.

15. Henricot, B., and Culham, A. 2002. Cylindrocladium buxicola, a new species affecting Buxus spp., and its phylogenetic status. Mycologia 94:980-997.

16. Henricot, B., David, J., Ivors, K., Heungens, K., Spooner, B., Pérez Sierra, A., and Daughtrey, M. L. 2012. Proposal to conserve the name Cylindrocladium buxicola against C. pseudonaviculatum (Ascomycota). Taxon 61:1119-1120.

17. Henricot, B., Gorton, C., Denton, G., and Denton, J. 2008. Studies on the control of Cylindrocladium buxicola using fungicides and host resistance. Plant Dis. 98:1273-1279.

18. Henricot, B., Pérez Sierra, A., and Prior, C. 2000. A new blight disease on Buxus in the UK caused by the fungus Cylindrocladium. Plant Pathol. 49:805.

19. Hoffman, L. E., and Wilcox, W. F. 2003. Factors influencing the efficacy of myclobutanil and azoxystrobin for control of grape black rot. Plant Dis. 87:273281.

20. Ivors, K., Lacey, L. W., Douglas, S. M., Inman, M. K., Marra, R. E., and LaMondia, J. 2012. First report of Boxwood blight caused by Cylindrocladium pseudonaviculatum in the United States. Plant Dis. 96:1070.

21. Kuo, K. C., Lee, C. Y., Chiang, S. S., and Zheng, Y. S. 1999. Causal agent, pathogenesis and fungicide screening of lima bean anthracnose. Plant Prot. Bull. (Taichung) 41:265-275.

22. Lainsbury, M. A., ed. The UK Pesticide Guide 2009. BCPC and CABI.

23. Payne, R. W., Harding, S. A., Murray, D. A, Soutar, D. M. , Baird, D. B., Glaser, A. I., Channing ,I. C., Welham, S. J., Gilmour, A. R., Thompson, R., and Webster, R. 2009. Genstat for Windows, 12th Edn. VSN Intl., Hemel Hempstead.

24. Pintos Varela, C., Gonzáles Penalta, B., Mansilla Vázquez, J. P., and Again Casal, O. 2009. First report of Cylindrocladium buxicola on Buxus sempervirens in Spain. Plant Dis. 93:670.

25. Saracchi, M., Rocchi, F., Pizzatti, C., and Cortesi, P. 2008. Box blight, a new disease of Buxus in Italy caused by Cylindrocladium buxicola. J. Plant Pathol. 90:581-584.

26. Schöfl, U. A., and Zinkernagel, V. 1997. A test method based on microscopic assessments to determine curative and protectant fungicide properties against Septoria tritici. Plant Pathol. 46:545-556.

27. Wong, F. P., and Wilcox, W. F. 2001. Comparative physical modes of action of azoxystrobin, mancozeb and metalaxyl against Plasmopara viticola. Plant Dis. 85:649-656.

28. Xu, X. M., and Butt, D. J. 1996. Tests of fungicides for post-germination activity against Nectria galligena, causal agent of canker and fruit rot of apple. Crop Prot. 15:513-519. 